\title{
METHODOLOGICAL ISSUES IN MACRO COMPARATIVE RESEARCH: AN INTRODUCTION
}

\author{
Jeffrey Kentor \\ Department of Sociology \\ University of Utah \\ jeffrey.kentor@soc.utah.edu
}

This special issue of JWSR is the offspring of an ASA Political Economy of the World System session that I organized in 2007. My thanks to Andrew Jorgenson, co-editor of JWSR, who moderated the session and proposed that I put together a special issue on this topic. In turn, I asked Timothy Moran to join me as co-editor of this issue. Tim is one of the foremost quantitative macro-comparative sociologists in the country, and was the discussant on the PEWS panel. Tim provides a summary and discussion of the contributions in the conclusion. As it turns out, only two of the panel presentations are included in this issue. The other two were submitted in response to a general call for papers. All four manuscripts were peer reviewed.

Three of the articles in this issue overlap in ways that might not readily be apparent by their respective titles. Pablo Lapegna's article, "Ethnographers of the World...United? Current Debates on the Ethnographic Study of 'Globalization'," explores the ways in which field studies of individuals and locales can do more than inform our understanding of global processes. Lapegna argues that these studies are necessary to counter the notion that local processes are simply the homogenous outcomes of macro-level dynamics. Lapegna rejects the "local-global" duality, arguing that social organizations at any level, be it a small village or megalopolis, need to be considered in their own right. Ethnographies provide a "view from below" that understands these hierarchical linkages as a dynamic interactive ones, where actors at the local and national levels modify global "projects" in light of area specific conditions and cultures. In the second half of the paper, Lapegna provides a detailed discussion of the current debate surrounding two types of ethnographic study; multisite versus global perspectives. Lapegna does not take sides on this issue, leaving it instead to the reader to navigate these issues.

In "Puzzles in the Comparative Study of Frontiers: Problems, Some Solutions, and Methodological Implications" Thomas Hall considers the role of "frontiers" in macrocomparative research. In Hall's view, frontiers are an inherent characteristic of all world systems, which are constantly expanding, contracting, and interacting with other world systems over time and space. As such, frontiers provide a useful window on the changing dynamics of these

relationships. Hall's basic point is that frontiers can provide a useful mechanism for connecting the local and the global, both from the bottom-up and top-down. In other words, the study of frontier social processes can inform world-systemic processes as well as the ways in which world systems analysis can inform local human agency. Hall begins with a discussion of the definition(s) of a "frontier." He first tells us what a frontier is not. It isn't a border or boundary between two countries, nor is it the overlap between two states. The emphasis here is that it is not static or stationary. Rather, they are fundamentally indeterminate or "fuzzy." Hall stresses the active and changing nature of frontiers. His favorite definition is drawn from the metaphor of a biological membrane. Both are selectively permeable in terms of direction, content and quantity.

Copyright @2009, American Sociological Association, Volume XV, Number 1, Pages 1-2

ISSN 1076-156X 
Hall goes on to discuss in depth the characteristics of frontiers, emphasizing the (world-system) context and scale that determine the nature of these zones of interactions.

Lloyd, Mahutga, and De Leeuw's article on, "Looking Back and Forging Ahead: Thirty Years of Social Network Research on the World-System," is an impressive review of the application of social network analysis (SNA) to world-systems analysis that will undoubtedly find its way onto many graduate student preliminary exam reading lists for its clear and thorough summary of the key concepts, benefits, and drawbacks, to using SNA to empirically study world systems processes. I will certainly add it to ours. LM\&D begin by exploring the notion of a "relational-structural" methodology that they argue is particularly useful in studying these global processes. They incorporate into this discussion a comprehensive review of the relevant literature. LM\&D close with their own assessment of the future methodological and substantive directions for SNA and world-systems analysis.

So what do these three articles have in common? All of these papers deal with the nature of the local-global relationship. And they all reject the pervasive tendency to understand the "local" as the passive expression of "global" processes. In its place, these authors stress the reciprocal, interactive nature of this dynamic. This is a welcome advance to macro-comparative research in general, and specifically to orthodox world-systems theory.

Salvatore Babones' contribution, "Modeling Error in Quantitative Macro-Comparative Research" will likely be the most controversial article of this issue. Babones highlights a critical and not widely-recognized nor well-appreciated statistical problem with quantitative longitudinal analyses; the misspecification of error in trended data. Babones provides the reader with a clear and comprehensive primer on some of the major problems encountered in quantitative macrocomparative research, focusing specifically on the issue of modeling error in the data that arise from heterogeneity bias and residual autocorrelation. Babones argues that the currently accepted, "hegemonic" methods of dealing with these issues, fixed and random effects panel models, can generate "wildly spurious results." He calls for a return to traditional "difference" models, in which change over time in the dependent variable is regressed on changes in the independent variable. In his critique, Babones boldly calls into question much of the currently published research in quantitative macro-comparative research, a position that is likely to draw a critical response from those who are using these hierarchical models in their work. This is indeed a crucial issue, and it is unlikely that Babones' article will be the final word on this topic. A critical dialogue between proponents and dissenters would be a worthy topic for another special issue of the Journal of World Systems Research. 


\title{
ETHNOGRAPHERS OF THE WORLD...UNITED? CURRENT DEBATES ON THE ETHNOGRAPHIC STUDY OF "GLOBALIZATION"1
}

\author{
Pablo Lapegna \\ Department of Sociology \\ State University of New York at Stony Brook \\ plapegna@ic.sunysb.edu
}

\begin{abstract}
How does ethnography come to terms with our current "global condition"? Being a method characterized by its in-depth knowledge of a bounded space, how does ethnography cope with a world scale? How does the "global condition" affect the definitions of key ethnographic concepts? In this article, I first reconstruct ethnographic debates regarding the status of "the global," showing how ethnography can contribute to a more nuanced understanding of the binary global/local. Then I review two projects that study global processes from an ethnographic point of view: multi-site ethnography (Marcus 1995) and global ethnography (Burawoy et al. 2000). I compare these two approaches along four dimensions: site, context, research design and reflexivity. I argue that while multi-site ethnography and global ethnography are often used interchangeably, each ultimately presents distinctive answers to key questions for the ethnographic study of global processes.
\end{abstract}

\section{INTRODUCTION}

If we think of ethnography as a method practiced in a delimited geographical space by engaging in face-to-face interactions, it is hard to imagine how such a "micro-oriented" perspective may render significant insights on something as wide as "the world." Imagined in those terms, the encounter between ethnography and "the global" poses nothing but an oxymoron:

After all, in anthropology, we stereotypically picture the lone ethnographer settled in his or her village, itself isolated from the world around. In sociology, we think of the ethnographer as the specialist of face-to-face relations or of situational analysis, but with the context firmly bracketed. (Burawoy 2001:147)

How do ethnographers deal with this problem of scale? How can an "intimate" method such as ethnography observe processes spanning the globe? Despite the oxymoronic nature of the enterprise, a series of scholars have analyzed global processes ethnographically (e.g. Ferguson

${ }^{1}$ I am grateful to Eileen Otis, Javier Auyero and Tim Moran for their critical comments on an earlier version of this paper. Any mistakes and omissions are mine. 
1994; Goldman 2001; Hannerz 1996, 2003; Comaroff and Comaroff 2003; Tsing 2005; Englund 2002) engaging cultural analyses of globalization and transnationalism (e.g. Kearney 1995; Appadurai 1996; Mintz 1998; Amselle 2002; Ong and Collier 2005). In this article I concentrate on the theoretical and epistemological debates surrounding ethnographic analyses of global processes by posing two main questions about ethnographic research on "globalization:"2 How do ethnographers understand global processes? How does the "global condition" affect traditional definitions ethnographic research? How can we understand fieldwork and its concomitant theoretical and epistemological problems in the light of our "global condition?" To address these questions, in the first part of the paper I analyze how ethnographers have solved the conundrum of using a method traditionally performed in small scale societies to address the global. I pay particular attention to ethnographers' criticisms of analyses of "the global" grounded in an overdeterministic political economy. I then examine how these ethnographers resolve the global/local binarisms that inform so many studies on global processes. Then, in the second part of the paper, I scrutinize two contrasting perspectives: multi-site ethnography (MSE) and global ethnography (GE). I concentrate on MSE and GE because they represent well-articulated and predominating methodological approaches to the study of globalization. While others have investigated the global from an ethnographic perspective, they do not propose a broader framework suitable for adoption by other researchers, as MSE and GE have done. I closely compare the ways in which MSE and GE approach four key issues in the ethnographic study of globalization: sites, context, research design and reflexivity. Although the analysis of these terms does not exhaust the possible lines of inquiry, they are the major methodological arenas in which ethnographers confront the challenges of incorporating an analysis of global processes. They all point out to emergent problems of ethnographic research regarding fieldwork and the production of theory and texts (e.g. Clifford and Marcus 1986; Van Maanen 1995; Strathern 1995; Amit 2000).

\section{TAPPING ON THE OXYMORON}

Can ethnography help achieve a better understanding of global processes? In this section, I discuss how ethnographers ${ }^{3}$ have conceptualized "the global" by addressing two interrelated problems. First, I will show how ethnographers have developed an alternative perspective on globalization by reviewing their major critiques of analyses of global processes rooted in political economic, organizational and sociological research. Second, I reconstruct the debates within ethnography regarding how we theorize and represent "globalization" in ethnographic terms, focusing on how ethnographers overcome the much criticized global/local binary.

Ethnographic perspectives had criticized conceptions grounded in political science and sociology that see the world in terms of diffusion of institutional models and patterns (e.g. Meyer

\footnotetext{
${ }^{2}$ I use the word globalization with quotation marks assuming that it is a twofold phenomenon of both processes in the "real world" and an ideological or cultural construct. Here I understand "globalization" as the increased density of interactions across boundaries and between institutions that produce, reward and regulate those interactions.

${ }^{3}$ Under "ethnographers" I conflate a variety of scholars that share a methodological approach dominant in anthropology but with critical contributions of sociology, geography and other social sciences.
} 


\section{JOURNAL OF WORLD-SYSTEMS RESEARCH}

et al. 1997) and/or in terms of "second modernity" (Giddens 1990). These ideas have one too many points of connection with "modernization" and its assumptions of universal institutional convergence to pass unnoticed from a cultural perspective (Tsing 2000). Ethnographers of the global point to the shortcomings of institutional frameworks of diffusion to consider the role of power in the global adoption of specific institutional models. Likewise, while notions of "structuration" (Giddens 1990) usefully conceptualize globalization as both enabling and constraining process, they fail to specify who is enabled and who is constrained (Burawoy 2000a). For some, the "privileged lifestyle of high-flying academics" overlooks how global processes are seen "from the underside" (Burawoy 2000b:337). "Global ethnographers" also take issue with teleological interpretations of global changes under recent capitalism. In those terms, most ethnographers of global processes seek an alternative to models that view globalization as dynamics that supposedly emanate from economically advanced centers and impose themselves as an external force on peripheries, with monolithic effects across spaces. Along these lines, global ethnographers find the interpretations of David Harvey (1989) and Frederic Jameson (1991) problematic to the extent that they trace the source of globalization to historical shifts in global capitalism that ultimately have homogeneous effects across different geographies. These grand theorists fail to identify how such processes are locally mediated with diverse effects on everyday life (Burawoy 2000).

Indeed, such views also tend to present an evolutionary picture of capitalism (Tsing 2005). Even at a global scale, capitalism is not a monolithic force; we should always bear in mind the paradoxical feature of capitalism: a social formation in continuous change that nevertheless maintains similar principles (Wallerstein 2004). Thus the assumption of a single world-capitalist system should not preclude questions about its heterogeneous formations and the diversity of projects involving global processes. In other words, we must resist the fallacy of globalism, i.e. the tendency to represent recent transformations in the world as processes given once and for all. Globalisms ("endorsements of the importance of the global") need to be interrogated as a set of projects "with their distinctive cultural commitments and their powerful but limited presence in the world" (Tsing 2000:330, 353). Put another way, the theories that see recent transformations as the gateway of a "new global era" understand those changes as an all-encompassing uniformity, taking as an assumption what in fact should be the point of departure for inquiry. Along those lines, Anna Tsing has argued that "If globalization can be predicted in advance there is nothing to learn from research except how the details support the plan" (2005:3).

As a method that requires immersion in a local setting and direct contact with informants, ethnography provides the ideal tools to investigate the diversities and heterogeneous manifestations of world-wide capitalism. By "ascending from the local to the global" an ethnographic gaze avoids the perils of assuming "that one can characterize changes of the whole without examining changes of the parts or, to put it the other way round, that the secret of the part can be found in the whole" (Burawoy 2000b:343). By placing in the foreground the "passions and the stakes of global connection" we can avoid the "structures of self-fulfillment" promoted by neoliberal globalization and "immerse ourselves in the drama of uncertainty of global capitalism and transnational liberalism" (Tsing 2005:269). Approaching "globalization" from such an ethnographic perspective circumvents the persistent identification of the global with the universal and the local with the particular, a conflation of level of analysis and geographical scale (Gille and Ó Riain 2002:286). Scholars that propose a research agenda based on GE propose that in "multiscalar research we cannot identify a priori a dominant level of analysis. How do we identify 
the limits of a community we are studying when the community is constituted across a variety of spatial scales (local, national, global, transnational, etc.)?" (Gille and Ó Riain 2002:286). As an ethnographic assumption, then, we should not take these projects and descriptions as natural "by assuming that the terms they offer us are true" (Tsing 2000:351), but rather, view them as diverse analytic lenses through which globalization is perceived, legitimated, and even constructed.

What, then, can ethnography offer to research on the current "global condition"? An ethnographic focus and its "concern with concrete, lived experience can sharpen the abstractions of globalization theories into more precise and meaningful conceptual tools" (Burawoy et al. 2000:xiv). Ethnographic studies of global process can help, for instance, to counterbalance the overemphasis on circulation of the "globalization" jargon. ${ }^{4}$ The buzzwords of flow and circulation, so often used in market models (Tsing 2000) and the emphasis in connections and mobility to describe global processes should not obscure the disconnection and irrelevance created by the same phenomena that inspires that language. An overemphasis on an imagery of connection leads Graeber to claim, "most anthropologists feel instantly uneasy with any formulation on globalization that even appears to cheerfully divide the world into those plugged in, and those not" (Graeber 2002:1223). Accordingly, some ethnographers have avoided a reification of mobility inspecting "the immobilities and experiences of confinement" produced by international practices (Navaro-Yashin 2003). In the same vein, others have argued that certain subjectivities have "escaped the discursive, productive constraints of globalization only because global forces have lacked the flexibility to capture and mobilize this subjectivity - it is not the heroism of resistance, but the abjection produced by a system that leaves people in those 'unprofitable' zones crushed and forgotten" (Friedman 2007:423-424).

Accordingly, the attention to connections, disconnections, juxtapositions, forces and associations does not imply a division of the world into "global" and "local" areas. The dichotomy global/local is deemed as highly problematic in the ethnographic literature on global processes. We can hardly see the local "as the stopping point of global circulations" since "if flow itself always involves making terrain, there can be no territorial distinctions between the 'global' transcending of place and the 'local' making of places" (Tsing 2000:338). Put another way, the distinction between "global" forces and "local" places, "draws us into globalist fantasies by obscuring the ways that the cultural processes of all 'place' making and all 'force' making are both local and global, that is, both socially and culturally particular and productive of widely spreading interactions" (Tsing 2000:352, original emphasis). Michael Burawoy poses this idea stating that "globalization is not a cause but an effect of processes in hierarchical chains that span the world. In this productivist perspective the global-local antinomy is itself misleading, for if something is global there can be nothing outside that is local" (2001:156-7). Accordingly, George Marcus asserts a similar idea proposing "a research design of juxtapositions in which the global is

\footnotetext{
4 "The distinct contribution of ethnography to debates on globalism lies in its capacity to show the actual limits of the fantasies that the globalist imagination produces and the reality of blockades amid global and transnational flows" (Englund 2002:263).

5 Studying Northern Cyprus as a "no-man's land" Navaro-Yashin makes the point that "Anthropologies of globalization in the model of Appadurai's work fail to study the ways in which the very processes of transnationalism which supposedly promote mobility and flexibility, also engender the opposite: immobility, entrapment, confinement, incarceration" (Navaro-Yashin 2003:108).
} 


\section{JOURNAL OF WORLD-SYSTEMS RESEARCH}

collapsed into and made an integral part of parallel, related local situations rather than something monolithic or external to them" (1995:102).

Summing up, the literature focusing on "the global" from an ethnographic point of view seems to agree in that (1) "globalization" is a phenomena in the "real world" as much as it is a project (see also Holtzman 2004); i.e. analyses of global process usually intermingle descriptive and prescriptive elements; (2) we should not devise a sort of "division of labor" in which the global picture developed by macro-structural views is "filled in" by the ethnographic portrait of "the local"; and, following the latter, (3) the distinction global/local is schematic if not entirely misleading (see also Englund and Leach 2000). In short, the task of ethnography could not be considered as the description of local instances of global processes; however, ethnographic practice is always located. Ethnography is a method that depends on interaction, communication and participation in order to produce insightful contributions to social theory. Thus, how do these ethnographic proposals regarding "global conditions" translate into fieldwork? If processes are global, they can be found everywhere and therefore nowhere. Thus the question: "Where would one locate the global in order to study it?" (Tsing 2005:3). To address this inquiry, I turn now to the debates localizing the possibilities of ethnographic research in a global situation.

\section{ETHNOGRAPHIES OF THE GLOBAL ALONG FOUR DIMENSIONS}

How can we recognize "the global" in order to study "it"? Which approaches have been proposed for the ethnographic study of "globalization?" Which are their assumptions and shortcomings? How can we deal with the "lack of fit between the problems raised by a mobile, changing, globalizing world, on the one hand, and the resources provided by a method originally developed for studying supposedly small-scale societies, on the other" (Gupta and Ferguson 1997:3)? Two main strategies have been proposed to answer this question: on one hand, George Marcus's multisite ethnography (MSE), a perspective emerging from the deconstruction of "realist ethnographic authority" (Stacey 1999:689). On the other hand, global ethnography (GE), actualizing the legacy of critical theory and invigorating it with "ethnographic flesh." Although by now an extensive literature focuses on "globalization" from a sociological or anthropological perspective, I will focus here in MSE and GE since they are the most explicit answers given to how to use ethnography to analyze global processes. In the following pages, I develop a critical dialogue between MSE and GE comparing these perspectives along four sets of questions. First, what are the conceptions of "site(s)" in multi-sited and global ethnographies? What kind of field-site and fieldwork is envisioned in each of them? How do MSE and GE challenge traditional definitions of intense fieldwork in a delimited geographical area? Second, how do we determine the connections between the delimited spaces or communities entailed by the ethnographic research and the "external world"? Which kind of global phenomena can be captured through ethnography? Third, what kind of guidelines and orientations should we use for an ethnographic study of global processes? How do MSE and GE propose that ethnographers should collect data? Fourth, how do MSE and GE approach the ethnographer's "intervention?" How can we incorporate the presence of the ethnographer as a dimension of the analysis? The aim of this discussion is to show that MSE and GE are sometimes used as interchangeable concepts but ultimately present distinctive answers to key questions for the ethnographic study of global processes. 


\section{Site(s)}

The contestation of the geographically bounded fieldsite as the sole object of the ethnographer's practice is the founding principle of multi-sited ethnography. According to George Marcus, MSE "moves out from the single sites and local situations of conventional ethnographic research designs to examine the circulation of cultural meanings, objects, and identities in diffuse timespace" (1995:96). By doing so, MSE develops

de facto comparative dimensions... as a function of the fractured, discontinuous plane of movement and discovery among sites as one maps an object of study and need to posit logics of relationship, translation, and association among these sites. (Marcus 1995:102)

The guidelines provided by Marcus to practice MSE are defined as "modes of construction" by which the ethnographer follows people (e.g. migrants), things (e.g. the circulation of commodities, money, gifts, etc.), metaphors (discourses and modes of thought), plots, stories and allegories (typically, studying social memory), as well as biographies or conflicts (Marcus 1995:105-110). ${ }^{6}$ The ethnographer reconstructs the site through the links she/he creates doing fieldwork and connecting the sites through the text and the arguments.

Multi-site research is designed around chains, paths, threads, conjunctions, or juxtapositions of locations in which the ethnographer establishes some form of literal, physical presence, with an explicit, posited logic of association or connection among sites that in fact defines the argument of the ethnography. (Marcus 1995:105)

This often quoted paragraph certainly captures one of the basic points of MSE: the field site is understood less in terms of a space and more as connections, a series of "shifting locations" (Clifford 1997). The site is thus not necessarily a concrete space but rather a series of sites connected by a common thread; sites are put together by the ethnographer's argument. In such way, travel and mobility replace the classic ethnographic terms of dwelling and long-term fieldwork (Englund 2002.) As an example of multi-site research, Marcus quotes a project on violence in contemporary Colombia in which ethnography was practiced at two sites: among experts ("violentologists") and in the Constitutional Court (Marcus 1998:21-25). Although the researcher attempts to justify the election of these two sites, ${ }^{7}$ some have argued that in MSE "the problem...is not finding a diversity of leads to follow, but rather finding a way to contain this multiplicity' (Candea 2007:175). From a GE view, the problem with MSE lies in that "while

\footnotetext{
${ }^{6}$ Also some single site ethnographies are reanalyzed by Marcus as "strategically situated," on the grounds that they engage in an implicit comparison (the example is Paul Willis's Learning to Labor [1977] that looks at boys in school assuming they will become workers).

7 "I did not choose [those sites] for their structural similarities, or even for how they define networks of elites, but for the ways in which in its particular social manifestation and embeddedness defines possibilities for opening new public debates and terms of action in the consideration of the myriad forms and the past of violence in Colombia" (Marcus 1998:25).
} 


\section{JOURNAL OF WORLD-SYSTEMS RESEARCH}

finding connections is certainly not difficult, deciding which of them are worth pursuing seems somewhat arbitrary...[and] situations where clearly defined relations exists between two sites or across two scales are relatively rare" (Gille and Ó Riain 2002:286-287). For instance, the MSE strategy of "following the people" may be taken literally to study migrations, and an ethnographer can investigate migrants in their points of origin and destination. But if you take the example of "follow the metaphor", how can you determine which traces of a discourse to follow? If a discourse is produced in multiple points of a network, how can we know which node of the chain is more relevant?

From a GE perspective we cannot take sites literally, as Marcus seems to imply. We rather need to scrutinize how sites are produced, which politics of scale mold them and what hierarchies are (re)created in the process. GE thus proposes a research agenda to "replace abstract globalization with a grounded globalization that tries to understand not only the experience of globalization but also how that experience is produced in specific localities and how that productive process is a contested and thus a political accomplishment" (Burawoy 2001:158). In a way, GE takes heed of MSE debunking of the bounded site; yet it takes this insight into another direction. Proponents of a GE propose a perspective "that still locates itself firmly in places but which conceives those places as themselves globalized with multiple external connections, porous and contested boundaries, and social relations that are constructed across multiple spatial scales" (Gille and Ó Riain 2002:291). Therefore, the literal multiplicity of sites could be one among other strategies to investigate the causes and consequences of global process. Global ethnographers can also do research in one site by determining how it came to be imagined and created as a "local" place or how a place changed historically: "The place-bound site becomes a platform from which a variety of place-making projects can be investigated" (Gille and Ó Riain 2002:291).

Global ethnographies developing a "multi-site" strategy (by focusing on the movement of people and ideas) in part bear similarities with Marcus's ideas. Ethnographers studying software developers connecting Ireland and Silicon Valley (Ó Riain 2000), nurses connecting Kerala with USA (George 2000); and activists connecting USA and Brazil through feminist discourses (Thayer 2000) deploy methodological strategies similar to Marcus's "follow the people" or "follow the metaphor." However, how global ethnographers explain the movement of ideas and people differs from MSE (more on this in the following section). The main contrast between MSE and GE in their approaches to fieldsites is the use of ethnohistory in the latter to expand the "bounded site." For instance, in her study of the moribund welfare system in Hungary, Haney (2000) moved between state agencies observing and interviewing public officials, experts, and welfare recipients reshaping the practices and "discourses of need." But Haney broke not only with spatial but also with temporal borders; she perused the archives of a welfare agency to compare the discourses of welfare recipients before and after the fall of the socialist state. Therefore, through the use of ethnohistory she multiplied both the "geographic" and the temporal sites of research. Similarly, the work of Gille (2000) on the conflicts over the installation of a dump site in Hungary moves "backwards" tracing the past history of the locality and moves "upwards" investigating the multiple scales involved in the disputes between different actors (local towns, the global incinerator industry, the Green party, etc).

In short, GE (as MSE) concentrates on connections between sites, yet it does so with an

eye to how these connections (re)produce and destabilize hierarchies in the midst of historical change, scrutinizing the politics of scale implicit in the production of spaces. To explain change, 
movement and scales, GE necessarily connects their sites to broader forces, as I discuss in the following section.

\section{Context}

How can we make an argument about "global processes" using ethnography that, although multisited, researches a limited number of subjects, places or connections? In his programmatic review article, Marcus uses the concept of world-system as shorthand to refer to this "wider world"; yet the world-system is for him "not the theoretically constituted holistic frame that gives context to the contemporary study of peoples or local subjects closely observed by ethnographers, but it becomes, in a piecemeal way, integral to and embedded in discontinuous, multi-sited objects of study" (Marcus 1995: 97). A MSE perspective may accept the possibility of a "sort of total world system as long as the terms of any particular macro-construct of that system are not allowed to stand for the context of ethnographic work" (Marcus 1995:99). In other words, the context cannot be reconstructed by resorting to what he calls "grand narratives" or "disembedded macroperspectives" since ethnographers "are trying to come to terms in shaping their objects of study in the absence of reliable holistic models of macroprocesses for contextualizing referents of research, such as 'the world system,' 'capitalism,' 'the state,' 'the nation,' etc." (Marcus 1995: 103). When ethnographers use these "fictions of the whole" to make sense of the world in which they study, "the ethnographer cannot help but to import into the closely watched life of his knowable community of subjects unexamined assumptions and premises about the way the larger world really is" (Marcus 1998:33). In other words, we should not represent the world of others imposing our theoretical categories.

From a MSE perspective, the context is a problem in itself not adequately solved resorting to other "narratives;" "the broader context is in a sense entirely of the ethnographer's and his informants' own making, rather than attributable to more abstract and already morally loaded forces such as capitalism and colonialism" (Marcus 1998:121). In an anthropological twist, the perils of ethnocentrism are now transfigured and conjured as "theory-centrism." Marcus is here wielding an argument against political economy and historical ethnography, claiming that "its arguments and significance are not produced or given within the frame of ethnographic work itself but by the contextualizing discourses and narratives in which the ethnography comes to be embedded" (1998:13). In contrast, Comaroff and Comaroff have argued that while one too many ethnographers have been worried about "theory" usurping "others" representation of themselves; "the masters of the market, and powerful political pragmatists, fashion new modes of extraction, abstraction, and explanation" (2003:155). From this perspective, rooted in historical ethnography, the elusiveness of the current world does not preclude an attempt to explain it. For instance, the Comaroffs set out the "occult economy" in South Africa as a problem that may,

account for the workings of a metamorphosing capitalism that is both global in its reach and localized in its protean manifestations. Built into that problem is an effort to engage at once with the general and the particular, with variance and similarity, with continuity and rupture. (Comaroff and Comaroff 2003:158) 


\section{JOURNAL OF WORLD-SYSTEMS RESEARCH}

For Marcus, in contrast, this strategy is a form of holism that "might succumb to relying on 'canned' visions of what the world historical system is like" (Marcus 1998:39). ${ }^{8}$ Burawoy shares the critique to the "bounded site" made by MSE, yet on the grounds that the closure of the site is "militantly opposed to history and consideration of the extralocal context" (Burawoy 2000a:8). The logic that justifies the connections between sites or the historical changes of a site is explained by GE as a result of larger determinations or "global forces." For GE, ethnographies of global processes have to investigate how the forces of global economy -mediated through the still present national state- creates heterogeneous social formations depending on the accommodations, negotiations and resistances of the grounded "local" actors. From the GE perspective, the absence of any role for the nation-state in constituting place and relations between places is MSE's blind-spot:

If the early anthropologists reflected a period before the rise of the modern nation state, their contemporaries today have sprung straight from village to the world as though the nation had already deceased. (Burawoy 2000a:33; cf. Marcus 1994:427)

In a way, the project of GE is about determining the "broader context" of the global from different perspectives and attending to its variations, resistances, opportunities and accommodations, focusing on the multiform ways in which global capitalisms and nation states interact with "local" actors. In this way, GE avoids viewing "global forces" as inevitable and natural, and instead conceptualizes global forces "as themselves the product of contingent social processes" (Burawoy 2000a:29). Accordingly, global forces can create global connections rendering counterintuitive results. For instance, in her research of migrant nurses traveling from Kerala, India to Central City, USA, Sheba George (2000) explains how economic dislocations create the conditions for migration and at the same time how this process transforms gender hierarchies within Indian families living in USA.

One of the key strategies of GE in elucidating the "broader context" of an ethnographic research is the use of ethno-history, a strategy at odds with the MSE perspective. Marcus, takes issue with historical-ethnographic explanations because they "....are not produced or given within the frame of ethnographic work itself but by the contextualizing discourses in which the ethnography comes to be embedded" (Marcus 1998:13). He argues that:

Anthropologists are more actively selecting framing contexts, theoretical associations, and narratives for their ethnography, but they still mostly are not creating them within the heart of the ethnographic process of fieldwork and writing itself. (Marcus 1998:13)

\footnotetext{
${ }^{8}$ In a similar vein, the project of MSE also rejects a frame inspired in Jurgen Habermas's division of "life-world" and "system." When characterizing MSE, Marcus defines it as a "mobile ethnography" that "destabilizes the distinction, for example, between life-world and system, by which much ethnography has been conceived" (1995:96). Not surprisingly, this framework is explicitly deployed in the articles collected in Burawoy's Ethnography Unbound (1991).
} 
In contrast, from the point of view of GE the main problem of MSE is precisely that it neglects any assessment of the effects of historical legacies. Thus MSE

ignores the dynamic process by which sites are transformed by their external connections...It takes places for granted and leaves no room for accounting for the production and transformation of sites. In short, in multisited ethnography, history remains an afterthought rather than a factor that has implications for what can be seen as a site. (Gille and Ó Riain 2002:287-8)

To remedy the problem of "postmodern fracturing and fragmentation" of studies that become "a pastiche of vignettes" with ethnographers acting as "tourists tripping from resort to resort" Michael Burawoy proposes to "...ground our ethnographies in local histories" and turn ethnographies in ethnohistories (2000a:5). A GE perspective cannot but take history into account, since when reading local contexts ethnographically signs and practices

require to be inserted into the translocal processes of which they are part $a b$ initio: processes -commodification, colonization, proletarianization, and the likecomposed of a plethora of acts, facts, and utterances whose very description demands that we frame them in the terms of one or other Theory of History. (Comaroff and Comaroff 2003:161)

By tracing historical change, GE follows scholars arguing that the key task is not only to make conceptual connections between places and theory but also to make historical connections between places, which in turn help us to advance in both our understanding of particular people and the refinement of theory (Des Chene 1997). One of the ways in which GE introduces history into ethnographic research is by revisiting sites previously studied or using existing ethnographies as a historical baseline that allows one to observe changes produced in the site/s. This strategy has been formalized as the "extended case method," originally developed by the Manchester School (Van Velsen 1967; Gluckman 1967) and developed by Burawoy (1998). GE explicitly relies on this strategy, which lead us to consider first how GE and then how MSE conceive the research design.

\section{Research Design}

GE seems to join recent trends in ethnographic research emphasizing its explanatory and analytical capacities (e.g. Lofland 1995; Katz 2001, 2002; Snow, Morril and Anderson 2003). The research design proposed by GE is a dimension of the extended case method. For practitioners of GE, the objective of research is to strengthen and extend theory by accommodating "observed lacunae or anomalies:" "We try to constitute the field as a challenge to some theory we want to improve. What makes the field 'interesting' is its violation of some expectation and an expectation is nothing other than some theory waiting to be explicated" (Burawoy 2000a:28). For GE adherents, without the guidance of theory it becomes impossible to 


\section{JOURNAL OF WORLD-SYSTEMS RESEARCH}

know where to look, what to ask or what fieldnotes to take. ${ }^{9}$ Conversely, the Comaroffs advocate for anthropology "empirically grounded without being empiricist" (2003:164) to address the research of global configurations from an ethnographic perspective. ${ }^{10}$ Albeit taking note of the recent "anthropological anxieties" brought by the postmodern critique, these ethnographers maintain the need of relying in theory:

the human world, post-anything and everything, remains the product of discernible social and cultural processes: processes partially indeterminate yet, in some measure, systematically determined; ambiguous and polyvalent, yet never utterly incoherent and meaningless; open to multiple constructions and contest, yet never entirely free of order - or the reality of power and constraint. (Comaroff and Comaroff 1992:xi) ${ }^{11}$

In a nutshell, portraying fieldwork as a mere "look and see" done without the guidance of theory is unacceptable from a GE perspective. Ethnographers inevitably always perceive, register and interact in the field with the aid of a theory, consciously or unconsciously. Theory and data inform each other, yet theory makes data possible and gives it its significance; the final aim of fieldwork from a GE view is to construct sound explanations of social phenomena developing social theory. The potential pitfall of the emphasis on theory is that it may render monolithic descriptions of the people studied; missing variations of behavior that may defy the theoretical frame (Katz 2004). In fact, one of the critiques of the founding statement of GE, is that some of the case studies "lack a substantial ethnographic component, relying instead on either historical data or scholarly interpretation. This leaves the reader with little sense of how the people most affected by the forces of globalization conceptualize, react to, or combat them." (Hargrove 2001:39; also see Burawoy et al. 2000).

MSE, in turn, has a quite different stance regarding the role of theory in the practice of fieldwork. In Marcus's perspective, "theory is held in abeyance" since it is in the experience of moving between field-sites that the ethnographer avoids the perils of "overtheorization." In MSE, the theory emerges when positing a logic of relationship between the sites where the ethnography is conducted (Marcus 1998:19). ${ }^{12}$ Theory may constrict the ethnographer's fieldwork by way of introducing preconceptions:

${ }^{9}$ Taking to its paroxysm, the idea of doing fieldwork "without theory" equates the ethnographer with a character of a Jorge Luis Borges' short story, Funes, whose ability to remember everything made him incapable of abstraction (Borges 1967). I owe this telling metaphor to Javier Auyero.

${ }^{10}$ See also the article by Comaroff and Comaroff (2003:168-170) for guidelines on the "methodological operations" to address these problems.

${ }^{11}$ In the same vein, in a "Manifesto for Ethnography" (the opening editorial of the journal Ethnography) the authors underlie the same preoccupation: "We are not interested in 'grand theory,' 'pure' scholastic reason, or 'abstracted' empiricism. We seek to promote 'theoretical informed-ness,' 'sensitizing concepts,' 'analytic points,' all means of teasing out patterns from the texture of everyday life, from 'pure' descriptive ethnography" (Willis and Trondman 2000).

12 "Anthropologists are more actively selecting framing contexts, theoretical associations, and narrative for their ethnography, but they still mostly are not creating them within the heart of the ethnographic process of fieldwork and writing itself" (Marcus 1998:13). 
For example, once we know (or analytically 'fix' by naming) that we are writing about violence, migration, the body, memory, and so forth, we have already circumscribed the space and dimensions of our objects of study...The mark of experimental, critical work is its resistance to this too-easy assimilation of the phenomenon of interest by any given analytic, ready-made concepts. (Marcus 1998:187-188)

In MSE, concepts commonly used to set the context of a research could only emerge from the fieldwork and its inscription in a text. Put another way, the fieldwork must inform theory and not the other way around. The ideal of research may sound familiar to sociologists utilizing qualitative methods, since MSE methodology resembles the inductive techniques of "grounded theory" (Glaser and Strauss 1967). The problem of this strategy is that may provide little guidance when the researcher has to make decisions in the field. For instance, Matei Candea, inspired by this spirit of MSE,

followed people, stories, metaphors, and debates through multiple spaces both within 'the village' and without [but] in practice [this] led to a constant indeterminacy: how many leads to follow? How much context to seek? How much information is enough information? (Candea 2007:173)

This is exactly the conundrum that MSE leaves for its practitioners, who risk a less than systematic investigation of "the field" for their reluctance to self-consciously adopt a set of theoretical questions at the outset.

\section{Reflexivity}

How ethnographies of global processes conceive the effects of the researcher's intervention in the places studied? How does physical and social immersion in a delimited setting required by the practice of ethnography affect representations of the world/s portrayed in global or multi-sited ethnographies? MSE and GE offer contrasting responses to these questions. The former requires the ethnographer to interrogate relationships of power, in particular the ways in which informants are represented in texts. The latter addresses the issue mainly by reflecting on the structural constraints that exert an influence in the ethnographer's categories of perception and analysis.

The different sites the researcher observes and participates in MSE demand a continuous change in the spaces of interaction. These changing landscapes traversed by the multi-sited ethnographer demand a perpetual renegotiation of her/his identity vis-à-vis the subjects of the study. The multisited ethnographer moves "between public and private spheres of activity, from official to subaltern contexts," and in this movement "it is bound to encounter discourses that overlap with his or her own" (Marcus 1995:112). The multi-site ethnography "is thus always conducted with a keen awareness of being within the landscape, and as the landscape changes across sites, the identity of the ethnographer requires renegotiation" (Marcus 1995:112). These changing conditions enable the ethnographer to gain insights about the ways she/he is perceived by others and the management of public presentation, both at the moment of fieldwork and the moment of writing. Reflexivity in MSE terms is then a twofold problem: a matter of analysis 


\section{JOURNAL OF WORLD-SYSTEMS RESEARCH}

about the unstable identity of the ethnographer in a variety of field sites, and a dimension in the practice of writing (see also Clifford and Marcus 1986; Peirano 1998). Turning the postmodern critique against Marcus, some have argued that the idea of ethnographer facing a "rupture" when moving between settings is problematic, since this will suppose a unitary identity that precedes the entrance to the field (Roberts and Sanders 2005). This indictment is especially pertinent for "halfie" ethnographers (Abu-Lughod 1991) that neither fit in the typical mold of the "white anthropologist" nor necessarily in the role of "native." Yet beyond these critiques, what I would like to stress here is that reflexivity in terms of MSE turns its gaze towards silences in classical anthropology (namely, the omniscient narrator that bracketed colonialism) by scrutinizing the self of the ethnographer and her/his techniques of representation. ${ }^{13}$ Reflexivity according to MSE thus implies a focus on the ethnographer's identity and her/his relationships with others, which are inspected in the practice of fieldwork and in the texts produced.

Whereas MSE focuses its attention on the effects of power relations in the text (i.e. the "politics of representation") and the changes in the ethnographer's persona (her/his different "strategies of presentation" according to the context), GE considers how the ethnographer's intervention could be a tool to scrutinize its categories of perception and its effects in the world she/he studies. GE researchers react against trends that view ethnography as akin to comparative literature, "an interpretative exercise, a political stance, which justifies the thinnest of accounts, the most fleeting of engagements, and the most unsystematic of observations" (Burawoy 2000b: 341). In other words, GE is less preoccupied in textual experimentation than in avoiding a picture of "the global" that is a function of the socially privileged position of the researcher. Allow me to quote in extenso a passage of Burawoy's conclusion of the volume Global Ethnography in order to illustrate this point:

It is an accident that high-flying academics, hotel circuiting consultants, conference-hopping professionals, and netscaping virtuosos should develop concepts of the network society, should imagine a manichean world of placeless power and powerless places, should expound on time-space compression or aesthetic cognitive maps? ... Their theories of globalization are theories of privileged men, who appear in a privileged air-space above the world they theorize. Their absence from their own accounts aspires to objectivity, but it cannot hide the unspoken, unreflected, stratospheric situatedness of their knowledges. How much of their theorizing is the projection of insulated journeys, unspoken genealogies, self-referential worlds? (Burawoy et al. 2000:340)

Put another way, if one of the basic tenets of ethnography is to avoid ethnocentrism, we should also be wary of falling into "class-centrism." Burawoy's critique aims more towards

${ }^{13}$ In certain passages, Marcus (1998) also seems to take note of the institutional patterns that shape research. See, for instance, his discussion of the different inquiries posed by ethnographers in their "first" (i.e. PhD dissertations) and "second" projects (i.e. once the ethnographer became established). 
"cosmopolitan sociologists" than to anthropologists, yet the point should not be disregarded, and perhaps these counterpoints between GE and MSE reflect disciplinary differences. ${ }^{14}$

A crucial way to exert a "reflexive vigilance" could be to scrutinize the conditions of production and circulation of the ethnographic studies of global processes. For instance, Englund and Leach remark that

the constant monitoring of scholarly output...presuppose continuous presence in the academia...Unsurprisingly, perspectives which require a minimum of fieldwork, perspectives which demand instant ethnography to illustrate aspects of a metropolitan meta-narrative, hold increasing appeal. (2000:238-9)

Others hold that "reflexivity within ethnography is not only affected by biographical resources...but also, perhaps more importantly, by research resources" (Roberts and Sanders 2005:309). This point is especially pertinent when considering how neoliberalism is reshaping universities (Hannerz 2007), or when discussing North-South relationships within the anthropological field (Lins Ribeiro 2006), and issues of power within the field of global sociology (Burawoy 2008). ${ }^{15}$ This broader issue is beyond the scope of this article, yet an important way to exert a reflexive stance is to de-naturalize not only the place of the ethnographer in the "exotic" field-site but also in the more familiar milieu of academic research (see also Bourdieu 1984; Bourdieu and Wacquant 1992).

In the preceding pages, I dissected the tenets of MSE and GE along four dimensions, an analysis which I attempt to summarize in Table 1.

Table 1: GE and MSE Along Four Dimensions

\begin{tabular}{|c|c|c|c|c|}
\hline & Site/s & Context & Research Design & Reflexivity \\
\hline $\begin{array}{l}\text { Global } \\
\text { Ethnography }\end{array}$ & $\begin{array}{l}\text { Different } \\
\text { scales }\end{array}$ & $\begin{array}{l}\text { Capitalism } \\
\text { Nation-Sate } \\
\text { History }\end{array}$ & Extension of theory & Structural position \\
\hline $\begin{array}{l}\text { Multi-site } \\
\text { Ethnography }\end{array}$ & $\begin{array}{l}\text { Different } \\
\text { locales }\end{array}$ & $\begin{array}{c}\text { "of the ethnographer's and } \\
\text { his informants' own } \\
\text { making" }\end{array}$ & $\begin{array}{c}\text { Theory "held in } \\
\text { abeyance" }\end{array}$ & $\begin{array}{l}\text { Self and textual } \\
\text { representation }\end{array}$ \\
\hline
\end{tabular}

${ }^{14}$ According to Paul Rabinow, "For many years, anthropologist informally discussed fieldwork experiences among themselves. Gossip about an anthropologist's field experiences was an important component of that person's reputation. But such matters were not, until recently, written about 'seriously'. It remains in the corridors and faculty clubs" (Rabinow 1986:253).

${ }^{15}$ Another point not sufficiently discussed is the influence of review boards and ethic committees that oversee ethnographic research, usually using a framework more suitable for the natural sciences. See for instance the special forum in American Ethnologist on "IRBs, Bureaucratic Regulation, and Academic Freedom" (2006, Vol. 33, No. 4) and also Cooper (2007); Bosk (2007); Lederman (2007); and Tolich and Fitzerald (2006). 


\section{JOURNAL OF WORLD-SYSTEMS RESEARCH}

In retrospect MSE had the virtue of widening the scope of anthropology, bringing it closer to cultural studies and sociology (although the "postmodern" sympathies of MSE fit better with the former than the latter). MSE spelled out what many ethnographers were already doing, providing a rationale to study transnational or global phenomena using participant observation, and loosening the straitjacket of the bounded field-site in anthropology.

MSE, in short, contributed to a conversation to denaturalize the field, fieldwork and its translation into texts. Akhil Gupta and James Ferguson nicely captured the implications of an unstable fieldwork by asserting that "We might emerge from such a move with less of a sense of 'the field' (in the 'among the so-and-so' sense) and more of a sense of a mode of study that cares about, and pays attention to, the interlocking of multiple social-political sites and locations" (1997:37) In his Ethnography Through Thick and Thin, Marcus (1998) somehow softened the agenda of MSE, asserting that multi-site strategies should be thought as "a research imaginary...rather than a set of methods that are very specifically prescriptive for the conduct of fieldwork and writing" (1998:6). Several scholars took heed of the methods and/or the imaginary proposed by Marcus's manifesto investigating global connections in the sub-areas of legal anthropology (e.g. Anders 2007; Merry 2000), transnational migrations and diasporas (e.g. Hall 2004; Fitzgerald 2006; see reviews in Routon 2006 and Santiago-Irizarry 2008) gender and work (e.g. Ganguly-Scrase 2003), multinational corporations and international management practices (e.g. Hassard, McCann and Morris 2007; Peltonen 2007), consumption relations (e.g. Bettany and Daly 2008), and commodity chains (Freidberg 2001). Still others have aimed to extend the methodological and theoretical insights of MSE (e.g. Bornstein 2007; Line 2007; Fitzgerald 2006). ${ }^{16}$ Nevertheless, some consider there is still certain lag between the programmatic gesture of MSE and the ethnographic research of global processes. ${ }^{17}$

If MSE brings sociology and anthropology closer, then GE reinvigorates ethnography within sociology. Unlike anthropology, where ethnography has been established as the canonic method, it has been marginalized in the discipline of sociology (see, for instance, the account of Burawoy 2000a:7-15). GE provides useful guidelines to study global processes ethnographically without accepting the postmodern premises of MSE. In other words, GE offers a toolkit for scholars interested in analyzing global process, allowing them to attend to local meanings without losing perspective of the mediating role of the national state or the impinging forces of global capitalism(s). Some researchers have followed these guidelines and produced work in the areas of migration (e.g. Paerregaard 2008), gender and work (Otis 2008; Poster 2002), the dynamics between global process and world's sub-regions (e.g. Chong 2007; Gille 2004), and the role of financial organisms in fostering "globalization" (e.g. Goldman 2006). With the hype about "globalization" now withering away, GE offers a significant point of departure to problematize

\footnotetext{
${ }^{16}$ See also Coleman and Von Hellerman (forthcoming) for a review of MSE.

${ }^{17}$ To witness, see the following appraisal in an anthropological forum: "If you were to mention a field, topic, or approach that is sorely lacking in current anthropological dealings with the global world what would that be? Only in the sense that there was this rush of programmatic announcements followed by a smaller number studies of diasporas, media forums, and corporate networks, so the actual ethnography of the global is still largely lacking. That is the reason I am saying we still need to work at the methods, because if we are not counting programmatic statements we still have a very small corpus of ethnographic work. I think the question on how to do work on some of these new topics is still being worked out" (Hirsch et al. 2007:122).
} 
disembodied and abstract accounts of global processes (e.g. Giddens 1990; Beck 2005) and provides a perspective that can be reconciled and put into dialogue with sociological debates.

\section{CONCLUSION}

In this article I hope to have shown the contributions that ethnography can make to understanding, explaining and researching the contemporary "global situation." The first part of the article concentrated on discussions that may bring disciplinary reflexivity into the study of global processes. More specifically, recent global ethnographers caution us to avoid taking "globalization" for granted. Instead global ethnographers are urged to problematize ready-made concepts that describe as much as inscribe/prescribe the ways in which they imagine and investigate "the global" and "the local." Ethnography can counterbalance certain tendencies in the social sciences that see the global situation in economistic, totalizing, monolithic or evolutionary terms. An ethnographic perspective, always attentive to situations and interactions in concrete settings, can show that the global is not a unitary phenomena but a diversity of projects. Ethnography can help to ground globalization by showing how global "flows" always have to make terrain, i.e. how forces with global reach always interact with actors at the national and "local" scale. This contribution not only enhances our imaginations of the global providing a view "from below." In fact, one of the points ethnographers of the global have made is that ethnography do not need to be constricted to exemplify the "local impact" of global processes. Rather, ethnographic research has demonstrated that the pair global/local never has to be confused with a geographical scale (New York is not "more global" than a village of the so-called periphery) neither should be equated with the binary universal/particular. For global ethnographers, global and local are scales that are constructed as political projects (i.e. as a function of relations of power) and for MSE those are dimensions that must emerge from the point of view of the sites where the fieldwork is done and not assumed by fiat. Therefore, one of the contributions made by an ethnographic gaze is that it forces us to be more critical about concepts such as "globalization" or the binary global/local, demanding to perceive them as cultural constructs and not simple reflections of "what is going on in the world," thus avoiding the perils of a naïve constructivism or a positivistic realism.

In the second part of the article, I explored the counterpoints that can be inferred from a close reading of the projects proposing a "multi-site" or a "global" ethnography, focusing on four dimensions. These differences between MSE and GE can be seen as the effect of broader and older disputes. Broader, because they show how MSE and GE are embedded in larger changes affecting the social sciences, the "literary/hermeneutic turn" in the case of MSE (e.g. Marcus and Cushman 1982) and the impact of the "historical turn" in the case of GE. Older, because these contrasts can be interpreted as a re-edition of tensions between "cultural" and "material" orientations within anthropology, which although never purely or overtly stated they still survive in the everyday interactions and rites of the discipline (Winslow 2007). ${ }^{18}$

18 The contrasts between MSE and GE also may be reflecting disciplinary frictions between sociologists and anthropologists. See for example the following telling dialogue: 
As it can be inferred, the highlighted contrasts are methodological as much as theoretical and epistemological. Rather than categorize "multi-sited" or "global" ethnographies as mutually exclusive projects, the goal of the second section was modest. Basically I sought to clarify points of incommensurability between these two perspectives to caution scholars against using them interchangeably. ${ }^{19}$ Although I do not assert that MS and GE are necessarily incompatible, MSE and GE offer distinctive responses to similar theoretical and methodological questions. Although with parallel inquiries, the two approaches may lead researchers down divergent paths. For instance, a MSE perspective is related to post-modern epistemology and has a parallel stance visà-vis participant observation as "grounded theory." In contrast, a GE perspective is related to a critical or pragmatic realism and analytic ethnography.

We know that both "realist" and "postmodern" ethnographies have shortcomings and insights. The point of this article, however, was not to reach a "middle ground," taking what is more valuable in each perspective; neither was it to entertain abstract epistemological debates. Rather my aim was to enrich a pragmatist point of view about how we do ethnography. If, as some have argued, research is a process that entails continuous decision-making, then this review can be conceived as a provisional map that may help to inform those choices. ${ }^{20}$ Both MSE and GE can certainly be sources of inspiration, still my guess is that when the ethnographer has to submit a grant proposal or make sense of the data collected, she/he will probably realize that certain types of data are more readily illuminated with some categories of questions, perspectives and authors over others. In conclusion, this article may be seen as an exercise and a map aimed to contribute towards post-globalist ethnographies.

\section{REFERENCES}

Abu-Lughod, Lila. 1991. "Writing Against Culture.” Pp. 137-162 in Recapturing Anthropology, edited by Richard Fox. Santa Fe, NM: School of American Research Press.

Amit, Vered, ed. 2000. Constructing the Field: Ethnographic Fieldwork in the Contemporary World. New York: Routledge.

Amselle, Jean-Loup. 2002. "Globalization and the Future of Anthropology." African Affairs 101: 213-229.

Anna Tsing: "When I talk to my students about the kinds of ways that they are copying students from other disciplines, it seems to be one of the distinctive requirements that we think about theory and our empirical material together. We do not separate them out as two layers."

Emily Martin: "Sociologists do that, right?"

Ann Tsing: "Right."

Emily Martin: "We do not want to make them the model, though." (Hirsch et al. 2007:115-116)

${ }^{19}$ Several papers present MSE and GE as synonyms. See, for instance, the articles of GangulyScrase (2003:550), Brown (2003:1793), Peltonen (2007:349), Hassard et al. (2007) and Freidberg (2001).

20 "As every researcher knows, there is more to doing research that is dreamt of in philosophies of science... No matter how carefully one plans in advance, research is designed in the course of its execution. The finished monograph is the result of hundreds of decisions, large and small, made while the research is under way" (Becker 1965:602). 
Anders, Gerhard. 2007. "Follow the Trial: Some Notes on the Ethnography of International Criminal Justice." Anthropology Today 23(3):23-26.

Appadurai, Arjun. 1996. Modernity at Large. Minneapolis: University of Minnesota Press.

Beck, Ulrich. 2005. Power in the Global Age. Malden MA: Polity Press.

Becker, Howard S. 1965. Review of Sociologists at Work: Essays on the Craft of Social Research by Philip E. Hammond. American Sociological Review 30(4): 602-603.

Bettany, Shona and Rory Daly. 2008. "Figuring Companion-Species Consumption: A Multi-Site Ethnography of the Post-Canine Afghan Hound." Journal of Business Research 61:408418.

Borges, Jorge Luis. 1967. "Funes, the Memorious." Pp. 35-43 in A Personal Anthology, edited by J. L. Borges. New York: Grove Press.

Bornstein, Erica. 2007. "Harmonic Dissonance: Reflections on Dwelling in the Field" Ethnos 72(4):483-508.

Bosk, Charles. 2007. "The New Bureaucracies of Virtue or When Form Fails to Follow Function" PoLAR: Political and Legal Anthropology Review. 30(2):192-209.

Bourdieu, Pierre and Loïc Wacquant. 1992. An Invitation to Reflexive Sociology. Chicago: The University of Chicago Press.

Bourdieu, Pierre. 1988. Homo academicus. Cambridge: Polity Press.

Brown, Phil. 2003. "Qualitative Methods in Environmental Health Research" Environmental Health Perspectives 111(14):1789-1798.

Burawoy, Michael. 2008. "Rejoinder: For a Subaltern Global Sociology?" Current Sociology 56: 435-444.

. 2003. "Revisits: An Outline of a Theory of Reflexive Ethnography" American Sociological Review 68:646-679.

. 2000a. "Introduction: Reaching for the Global." Pp. 1-40 in Global Ethnography: Forces, Connections, and Imagination in a Postmodern World, edited by Michael Burawoy, Joseph A. Blum, Sheba George, Zsuzsa Gille, Teresa Gowen, Lynne Haney, Maren Klawiter, Steven H. Lopez, Seán Ó Riain, and Millie Thayer. Berkeley and Los Angeles: University of California Press.

. 2000b. "Grounding Globalization." Pp. 337-350 in Global Ethnography: Forces, Connections, and Imagination in a Postmodern World, edited by Michael Burawoy, Joseph A. Blum, Sheba George, Zsuzsa Gille, Teresa Gowen, Lynne Haney, Maren Klawiter, Steven H. Lopez, Seán Ó Riain, and Millie Thayer. Berkeley and Los Angeles: University of California Press.

. 2001. "Manufacturing the Global" Ethnography 2(2):147-159.

. 1998. "The Extended Case Method" Sociological Theory 16:4-33.

. 1991. Ethnography Unbound. Berkeley and Los Angeles: University of California Press.

Burawoy, Michael, Joseph A. Blum, Sheba George, Zsuzsa Gille, Theresa Gowan, Lynne Haney, Maren Klawiter, Steven H. Lopez, Seán Ó Riain, and Millie Thayer. 2000. Global Ethnography: Forces, Connections, and Imaginations in a Postmodern World. Berkeley and Los Angeles: University of California Press.

Candea, Matei. 2007. "Arbitrary Locations: In Defense of the Bounded Field-Site" Journal of the Royal Anthropological Institute 13:167-184.

Chong, Terence. 2007. "Practising Global Ethnography in Southeast Asia: Reconciling Area Studies with Globalisation Theory." Asian Studies Review 31(3):211-226. 


\section{JOURNAL OF WORLD-SYSTEMS RESEARCH}

Clifford, James and George E. Marcus. 1986. Writing Culture. The Poetics and Politics of Ethnography. Berkeley and Los Angeles: University of California Press.

Clifford, James. 1997. "Spatial Practices: Fieldwork, Travel, and the Disciplining of Anthropology." Pp. 185-222 in Anthropological Location: Boundaries and Grounds of a Field Science, edited by Akhil Gupta and James Ferguson, Berkeley and Los Angeles: University of California Press.

Coleman, Simon and Pauline Von Hellermann, eds. Forthcoming. The Problems and Possibilities of Multi-sited Ethnography. New York: Routledge.

Comaroff, John and Jean Comaroff. 2003. "Ethnography on an Awkward Scale: Postcolonial Anthropology and the Violence of Abstraction." Ethnography 4(2):147-179.

Comaroff, Jean and John Comaroff. 1992. Ethnography and the Historical Imagination. Boulder, Colo.: Westview Press.

Cooper, Matthew. 2007. "Sharing Data and Results in Ethnographic Research: Why This Should not be an Ethical Imperative." Journal of Empirical Research on Human Research Ethics 2(1):3-19.

Des Chene, Mary. 1997. "Locating the Past." Pp. 66-85 in Anthropological Locations. Boundaries and Grounds of a Field Science, edited by Akhil Gupta and James Ferguson. Berkeley and Los Angeles: University of California Press.

Englund, Harri. 2002. "Ethnography After Globalism: Migration And Emplacement In Malawi." American Ethnologist 29(2):261-286.

Englund, Harri and James Leach. 2000. "Ethnography and the Meta-Narratives of Modernity." Current Anthropology 41(2):225-248.

Ferguson, James. 1994. The Anti-Politics Machine: "Development," Depoliticization, and Bureaucratic Power in Lesotho. Minneapolis and London: University of Minnesota Press.

Fitzgerald, David. 2006. "Towards a Theoretical Ethnography of Migration." Qualitative Sociology 29(1):1-24.

Freidberg, Susanne. 2001. "On the Trail of the Global Green Bean: Methodological Considerations in Multi-Site Ethnography." Global Networks 1(4):353-368.

Friedman, Jack. 2007. "Shock and Subjectivity in the Age of Globalization: Marginalization, Exclusion, and the Problem of Resistance." Anthropological Theory 7(4): 421-448.

Ganguly-Scrase, Ruchira. 2003. "Paradoxes of Globalization, Liberalization, and Gender Equality: The Worldviews of the Lower Middle Class in West Bengal, India." Gender and Society 17(4):544-566.

George, Sheba. 2000. “'Dirty Nurses' and 'Men Who Play': Gender and Class in Transnational Migration.” Pp. 144-174 in Global Ethnography: Forces, Connections, and Imagination in a Postmodern World, edited by Michael Burawoy, Joseph A. Blum, Sheba George, Zsuzsa Gille, Teresa Gowen, Lynne Haney, Maren Klawiter, Steven H. Lopez, Seán Ó Riain, and Millie Thayer. Berkeley and Los Angeles: University of California Press.

Giddens, Anthony. 1990. The Consequences of Modernity. Stanford: Stanford University Press.

Gille, Zsuzsa. 2000. "Cognitive Cartography in a European Wasteland: Multinational Capital and Greens Vie for Village Allegiance." Pp. 240-267 in Global Ethnography: Forces, Connections, and Imagination in a Postmodern World, edited by Michael Burawoy, Joseph A. Blum, Sheba George, Zsuzsa Gille, Teresa Gowen, Lynne Haney, Maren 
Klawiter, Steven H. Lopez, Seán Ó Riain, and Millie Thayer. Berkeley and Los Angeles: University of California Press.

. 2004. "Global Force, Connections, or Vision? The Three Meanings of Europe in PostSocialism." European Union Center Working Paper 4(2): 1-13.

Gille, Zsuzsa and Seán Ó Riain. 2002. "Global Ethnography." Annual Review of Sociology 28 : 271-95.

Glaser, Barney and Anselm Strauss. 1967. The Discovery of Grounded Theory: Strategies for Qualitative Research. New York: Aldine de Gruyter.

Gluckman, Max. 1967. The Judicial Process Among the Barotse of Northern Rhodesia. Manchester, UK: Manchester University Press.

Goldman, Michael. 2001. "The Birth of a Discipline: Producing Authoritative Green Knowledge, World Bank-Style." Ethnography 2(2):191-217.

Goldman, Michael. 2006. Imperial Nature. The World Bank and Struggles for Social Justice in the Age of Globalization. New Haven and London: Yale University Press.

Graeber, David. 2002. "The Anthropology of Globalization (with Notes on Neomedievalism, and the End of the Chinese Model of the Nation-State)." American Anthropologist 104(4):1222-1227.

Gupta, Akhil and James Ferguson. 1997. "Discipline and Practice: 'The Field' as Site, Method, and Location in Anthropology." Pp. 1-46 in Anthropological Locations: Boundaries and Grounds of a Field Science, edited by Akhil Gupta and James Ferguson. Berkeley and Los Angeles: University of California Press.

Hall, Kathleen D. 2004. "The Ethnography of Imagined Communities: The Cultural Production of Sikh Ethnicity in Britain." Annals of the American Academy of Political and Social Science 595:108-121.

Haney, Lynn. 2000. "Global Discourses of Need: Mythologizing and Pathologizing Welfare in Hungary." Pp. 48-73 in Global Ethnography: Forces, Connections, and Imagination in a Postmodern World, edited by Michael Burawoy, Joseph A. Blum, Sheba George, Zsuzsa Gille, Teresa Gowen, Lynne Haney, Maren Klawiter, Steven H. Lopez, Seán Ó Riain, and Millie Thayer. Berkeley and Los Angeles: University of California Press.

Hannerz, Ulf. 1996. Transnational Connections: Culture, People, Places. New York: Routledge. . 2003. "Being There...and There...and There! Reflections on Multi-site Ethnography." Ethnography 4(2):201-216.

. 2007. "The Neo-Liberal Cultural Complex and Universities: A Case for Urgent Anthropology?" Anthropology Today 23(5):1-2.

Hargrove, Melissa. 2001. "Global Ethnographies." Transforming Anthropology 10(2):38-40.

Harvey, David. 1989. The Condition of Postmodernity: An Enquiry into the Origins of Social Change. Oxford: Basil Blackwell.

Hassard, John, Leo McCann, Jonathan Morris. 2007. "At the Sharp End of New Organizational Ideologies: Ethnography and the Study of Multinationals." Ethnography 8(3):324-344.

Hirsch, Eric, Bruce Kapferer, Emily Martin, and Anna Tsing 2007. "Anthropology After Globalization." Ethnos 72(1):102-26.

Holtzman, Jon. 2004. "The Local in the Local: Models of Time and Space in Samburu District, Northern Kenya." Current Anthropology 45(1):61-84.

Jameson, Fredric. 1991. Postmodernism, or, The Cultural Logic of Late Capitalism. Durham: Duke University Press. 


\section{JOURNAL OF WORLD-SYSTEMS RESEARCH}

Katz, Jack. 2001. "From How to Why: On Luminous Description and Causal Inference in Ethnography (Part 1)." Ethnography 2(4):443-473.

2002. "From How to Why: On Luminous Description and Causal Inference in Ethnography (Part 2)." Ethnography 3(1):63-90.

. 2004. "On the Rhetoric and Politics of Ethnographic Methodology." Annals of the American Academy of Political and Social Science 595:280-308.

Kearney, Michael. 1995. "The Local and the Global: The Anthropology of Globalization and Transnationalism." Annual Review of Anthropology 24:547-565.

Lederman, Rena. 2007. "Comparative 'Research': A Modest Proposal Concerning the Object of Ethics Regulation.” Political and Legal Anthropology Review 30(2):305-327.

Line, Christine. 2007. "Multi-sited Ethnography as a Middle Range Methodology for Contemporary STS." Science, Technology \& Human Values 32(6):652-671.

Lins Ribeiro, Gustavo. 2006. "World Anthropologies. Cosmopolitics for a New Global Scenario in Anthropology." Critique of Anthropology 26(4):363-386.

Lofland, J. 1995. "Analytic Ethnography. Features, Failings, and Futures." Journal of Contemporary Ethnography 24(1):30-67.

Marcus, George. 1995. "Ethnography in/of the World System: The Emergence of Multi-Sited Ethnography." Annual Review of Anthropology 24:95-117. . 1994. "General Comments." Cultural Anthropology 9(3): 423-428. . 1998. Ethnography through Thick and Thin. Princeton, NJ: Princeton University Press.

Marcus, George and Dick Cushman. 1982. "Ethnographies as Texts." Annual Review of Anthropology 11:25-69.

Merry, Sally. 2000. "Crossing Boundaries: Ethnography in the Twenty-First Century" Political and Legal Anthropology Review 23(2):127-133.

Meyer, John, John Boli, George Thomas, and Francisco Ramirez. 1997. "World Society and the Nation-State." American Journal of Sociology 103:340-63.

Mintz, Sidney W. 1998. "The Localization of Anthropological Practice: From Area Studies to Transnationalism." Critique of Anthropology 18(2):117-133.

Navaro-Yashin, Yael. 2003. "'Life is Dead Here:' Sensing the Political in 'No Man's Land."” Anthropological Theory 3(1):107-125.

Ong, Aihwa and Stephen J. Collier. 2005. Global Assemblages: Technology, Politics, and Ethics as Anthropological Problems. Oxford: Blackwell Publishers.

Ó Riain, Seán. 2000. "Net-Working for a Living: Irish Software Developers in the Global Workplace.” Pp. 175-202 in Global Ethnography: Forces, Connections, and Imagination in a Postmodern World, edited by Michael Burawoy, Joseph A. Blum, Sheba George, Zsuzsa Gille, Teresa Gowen, Lynne Haney, Maren Klawiter, Steven H. Lopez, Seán Ó Riain, and Millie Thayer. Berkeley and Los Angeles: University of California Press.

Otis, Eileen. 2008. "Beyond the Industrial Paradigm: Market-Embedded Labor and the Gender Organization of Global Service Work in China." American Sociological Review 73(1): 15-36.

Paerregaard, Karsten. 2008. Peruvians Dispersed: A Global Ethnography of Migration. Lanham, MD: Lexington Books.

Peirano, Mariza. 1998. "When Anthropology is at Home: The Different Contexts of a Single Discipline." Annual Review of Anthropology 27:105-128. 
Peltonen, Tuomo. 2007. "In the Middle of Managers: Occupational Communities, Global Ethnography and the Multinationals." Ethnography 8(3):346-360.

Poster, Winifred R. 2002. "Racialism, Sexuality, and Masculinity: Gendering 'Global Ethnography' of the Workplace.” Social Politics 9:126-158.

Rabinow, Paul. 1986. "Representations Are Social Facts. Modernity and Post-Modernity in Anthropology." Pp. 234-261 in Writing Culture, edited by James Clifford and George Marcus. Berkeley and Los Angeles: University of California Press.

Roberts, John Michael and Teela Sanders. 2005. "Before, During and After: Realism, Reflexivity and Ethnography." The Sociological Review 53(2):294-313.

Routon, Kenneth. 2006. "Trance-Nationalism: Religious Imaginaries of Belonging in the Black Atlantic." Identities: Global Studies in Culture and Power 13:483-502.

Santiago-Irizarry, Vilma. 2008. "Transnationalism and Migration: Locating Sociocultural Practices Among Mexican Immigrants in the United States." Reviews in Anthropology 37(1):16-40.

Snow, David, Calvin Morril, and Leon Anderson. 2003. "Elaborating Analytic Ethnography. Linking Fieldwork and Theory." Ethnography 4(2):181-200.

Stacey, Judith. 1999. "Ethnography Confronts the Global Village: A New Home for a New Century?" Journal of Contemporary Ethnography 28:687-97.

Strathern, Marylin, ed. 1995. Shifting Contexts. Transformations in Anthropological Knowledge. London and New York: Routledge.

Thayer, Millie. 2000. "Traveling Feminisms: From Embodied Women to Gendered Citizenship." Pp. 203-233 in Global Ethnography: Forces, Connections, and Imagination in a Postmodern World, edited by Michael Burawoy, Joseph A. Blum, Sheba George, Zsuzsa Gille, Teresa Gowen, Lynne Haney, Maren Klawiter, Steven H. Lopez, Seán Ó Riain, and Millie Thayer. Berkeley and Los Angeles: University of California Press.

Tolich, Martin and Maureen H. Fitzerald. 2006. "If Ethics Committees were Designed for Ethnography." Journal of Empirical Research on Human Research Ethics 1(2):71-78.

Tsing, Anna. 2000. "The Global Situation." Cultural Anthropology 15(3):327-360.

. 2005. Friction. An Ethnography of Global Connection. Princeton and Oxford: Princeton University Press.

Van Maanen, John. 1995. Representation in Ethnography. Thousand Oaks, CA: Sage.

Van Velsen, Jaap. 1967. "The Extended Case Method and Situational Analysis.” Pp. 29-53 in The Craft of Urban Anthropology, edited by A.I. Epstein. London: Tavistock.

Wallerstein, Immanuel. 2004. World-Systems Analysis: An Introduction. Durham, NC: Duke University Press.

Willis, Paul. 1977. Learning to Labor: How Working Class Kids Get Working Class Jobs. New York: Columbia University Press.

Willis, Paul and Mats Trondman. 2000. "Manifesto for Ethnography." Ethnography 1(1): 5-16.

Winslow, Deborah. 2007. "Is Culture to Economy as Local is to Global? Travels with Anthropology's Renewed Ethnography." Reviews in Anthropology 36(1): 59-84. 